\title{
Editorial: in situ tests in geotechnical engineering
}

Myint Win Bo BSC, DUC, MSc, PhD, CEng, CGeol, CEnv, CSci, CMgr, PEng, PGeo, FICE, FGS, MCMI

President and CEO, Bo \& Associates Inc., Mississauga, Ontario, Canada

Ground investigation is the primary means of determining ground profile and characterising sub-surface materials encountered during ground investigation. Among the ground investigation methods, drilling boreholes to visualise the sub-surface materials, collecting sub-surface material samples such as soils and groundwater and carrying out in situ tests within boreholes are common practices for geotechnical and groundwater investigation purposes. While visualisation of soil samples would provide basic preliminary classification of soils, complete classification requires further laboratory tests on the collected samples. Despite the collected samples being good enough for the purpose of classification tests, these samples are usually disturbed to a certain extent, which generally affects the accurate measurements of strength, stiffness and compressibility of soils from the collected samples. It is well known that even the relatively good-quality undisturbed samples have a certain degree of disturbance as well as swelling and moisture loss caused by stress relief and exposure to the atmosphere. Due to that fact, it is extremely difficult to measure the strength and stiffness from collected samples under the in situ stress state or to reinstate or simulate the tests under a known in situ state. Therefore, measuring the strength and stiffness under in situ conditions within the boreholes is more and more popular, despite the fact that there may still be some levels of operational disturbance and stress changes.

Major methods of measuring in situ tests involve either applying dynamic or static forces or shearing forces on the soil masses and applying positive water pressures or suctions to the ground and pore waters for groundwater and pore water. Very early methods of estimating the strength of soils include the standard penetration test (SPT) and field vane shear test, while estimating stiffness and compressibility uses plate load tests. The earliest in situ testing, the SPT using a split-spoon sampler, was started in late 1927 by Gow Construction Co. in Boston (Rogers, 2006). During the last three decades significant developments of various kinds of in situ testing methods have been developed.

Among others, various scales of dynamic cone testing using light weight to super heavy weight, electronic static cone penetration testing in combination with pore pressure measurement (CPTU), seismic measurement (seismic cone), pressuremeter (cone pressuremeter), dilatometer (DMT) with seismic measurement and self-boring pressuremeter (SBPM) have proven very popular developments during the last two decades.
In addition to the in situ testing method using penetrating equipment, there are several other forms of in situ testing methods which are used to measure in situ stresses and deformation parameters during installation and construction. These include sensors attached to tunneling machines, installing piles and so on.

In situ tests either measure the geotechnical parameters directly or measure parameters which could be correlated with geotechnical parameters. Many correlations have been developed during the last three decades for various types of in situ test methods. Despite the various types of in situ tests developed during the last three decades, developments continue at a fast rate. Therefore, the Geotechnical Research editorial board considered approaching the industry to provide an update on the recent developments regarding in situ testing. This issue is the result of that approach.

This themed issue presents a few types of case histories involving the application of in situ testing methods.

The first paper (Bo et al., 2019) presents the application of specialised in situ tests such as the cone penetrometer test (CPT), DMT and SBPM in a land-reclamation and ground-improvement project in Changi, Singapore. These specialised in situ tests were not only utilised to profile and characterise the underlying soils, both granular and cohesive, this paper also discusses how these in situ testing methods were utilised to monitor and verify the progress of ground improvement and quality control of the land-reclamation and ground-improvement works. Details of ground investigation in the Changi project can also be found in the paper by Bo et al. (2017).

The second paper, by Hawkins (2019), presents a method of analysing holding test data collected during pore pressure dissipation using pressuremeter testing. Hawkins presents how consolidation characteristics of clays and the permeability could be determined using the pressuremeter holding test data. Various methods of analysis proposed in the past are compared in his study. The similarities of the test method to the piezocone dissipation test are explained, and the analysis methods compared. A new method of analysis is described, using an Excel spreadsheet that simulates the pressures and flows around a cylindrical object.

The third paper (Orense et al., 2019) presents the screw driving sounding (SDS) method to characterise the soil, which is relatively 
Geotechnical Research

Volume 6 Issue GR1
Editorial: in situ tests in geotechnical

engineering

Bo less expensive than commonly used in situ tests such as SPT, CPT and so on. The SDS test, which was developed in Japan, is portable, efficient and less expensive to operate but can measure more parameters, including the required torque, load, speed of penetration and rod friction, and thereby provides a robust way of characterising soil stratigraphy, especially for road and residential projects. SDS is suitable for testing a depth of $10-15 \mathrm{~m}$, and suitable for characterising shallow deposits. In the paper, the results of SDS application to various New Zealand sites are discussed. In addition, a number of correlations between SDS parameters and CPT/SPT data are presented.

In the fourth paper, Amici et al. (2019) present the in situ stress measurements during tunneling using twin tunnel boring machines (TBMs) for the Neelum Jhelum hydropower project, located in the Azad Kashmir region of north-east Pakistan in foothills of the Himalayas. The area of study has an overburden thickness of up to $2000 \mathrm{~m}$ and high tectonic stresses in very complex geology. These in situ stress measurements were utilised as an indication of likelihood and severity of rockbursts. The paper describes the in situ stress measurements that were carried out behind the two TBMs. In addition, the authors explain how these data were interpreted and integrated to support excavation, prevention and control of rockbursts, which provide tunnel safety and productivity.

The last paper, by Svinkin (2019), discusses extensively the sensible determination of pile capacity using dynamic methods. Svinkin has evaluated several case studies of determining pile ultimate capacity using dynamic methods. Based on the findings from these case studies, he proposes how the analysed data can be used to verify pile ultimate capacity and sensibly determine the pile capacity.

With these interesting case studies on in situ tests, the editorial board hopes that readers will be able to update themselves on the development of in situ tests in geotechnical engineering.

\section{REFERENCES}

Amici R, Peach G and Nadeem M (2019) TBM in Azad Kashmir region of Pakistan: in situ stress measurements for rockburst prevision. Geotechnical Research 6(1): 39-51, https://doi.org/10.1680/ jgere.18.00018.

Bo MW, Arulrajah A, Choa V, Horpibulsuk S and Samingthong W (2017) Research-oriented ground investigation projects at Changi, Singapore. Geotechnical Research 4(1): 30-46, https://doi.org/10.1680/ jgere.16.00018.

Bo MW, Lwin T and Choa V (2019) Application of specialised in situ tests in Changi East reclamation projects, Singapore. Geotechnical Research 6(1): 3-18, https://doi.org/10.1680/jgere.18.00033.

Hawkins PG (2019) The pressuremeter holding test, its analysis and similarity to the piezocone dissipation test. Geotechnical Research 6(1): 19-27, https://doi.org/10.1680/jgere.18.00023.

Orense RP, Mirjafari Y and Suemasa N (2019) Screw driving sounding: a new test for field characterisation. Geotechnical Research 6(1): 28-38, https://doi.org/10.1680/jgere.18.00024.

Rogers JD (2006) Subsurface exploration using the standard penetration test and cone penetrometer test. Environmental and Engineering Geoscience 12(2): 161-179.

Svinkin MR (2019) Sensible determination of pile capacity by dynamic methods. Geotechnical Research 6(1): 52-67, https://doi.org/10.1680/ jgere.18.00032. 